\title{
Effect of Different Level of Sulphur and Phosphorus on Growth and Yield Attributes of Sesamum
}

\author{
A.K. Pagal ${ }^{1 *}$, A.P. Singh ${ }^{1}$, S. Behera ${ }^{2}$ and C. Meher $^{3}$ \\ ${ }^{1}$ Department of Soil Science and Agricultural Chemistry, IAS, BHU, U. P, India \\ ${ }^{2}$ Krishi Vigyan Kendra, Kalahandi, Odisha, India \\ ${ }^{3}$ Agro Polytechnic Centre, Larkipali, Bolangir, Odisha, India \\ *Corresponding author
}

\section{A B S T R A C T}

\begin{tabular}{|l|}
\hline Ke y w or d s \\
Different level of \\
sulphur and \\
phosphorus, \\
Attributes. \\
\hline Article Info \\
\hline Accepted: \\
24 September 2017 \\
Available Online: \\
10 November 2017 \\
\hline
\end{tabular}

The present study in pot experiments was conducted on "effect of different level of sulphur and phosphorus on growth and yield attributes of sesamum (Sesamum indicum L.)". The treatments were taken in factorial completely randomized design in combination of four levels of $S\left(0,10,20\right.$ and $30 \mathrm{mg} \mathrm{kg}^{-1}$ of soil) and three levels of $\mathrm{P}\left(0,10\right.$ and $20 \mathrm{mg} \mathrm{kg}^{-1}$ of soil) applied through elemental sulphur and potassium dihydrogen phosphate, respectively. A recommended dose of $\mathrm{N}$ and $\mathrm{K}$ was applied with the treatments. A significant increase in seed and stalk yield of sesamum could be achieved by application of sulphur in an alluvial soil having high available phosphorus. Among the various treatments tested, maximum seed yield was obtained with combined application of $20 \mathrm{mg} \mathrm{kg}^{-1}$ phosphorus and sulphur which was $77.58 \%$ higher over control.

\section{Introduction}

Sesame (Sesamum indicum L.) is an important edible oilseed crop next to the groundnut, rapeseed and mustard in India. It is recognized by various names like gingely, til, simsim, gergelim and biniseed etc. About 70 per cent of the sesame produced in the country is used for oil extraction. Its oil content generally varies from 46 to 52 per cent which is highly resistant to oxidative rancidity. The protein content is around $25 \%$. Sesame oil is also referred to as "poor man's substitute for ghee". Sesame is called as 'Queen' of oilseeds. Oilseeds are important constituent in human dietary system next to carbohydrates and proteins (Shelke et al.,
2014). It is also a valuable nutritious feed for milch animals and is ingredient of poultry feed as it contains 6.0-6.2\% N, 2.0-2.2\% P and $1.0-1.2 \% \mathrm{~K}$. Globally, sesame is grown on 7.54 million hectare with production of 3.34 million tonnes and productivity of 448 $\mathrm{kg} \mathrm{ha}{ }^{-1}$. India is the largest producer and acreage holder $(26 \%)$ of the sesame in the world. In India, it is cultivated on 1.81 million hectares with total production of 0.76 million tones and productivity of $422 \mathrm{~kg} \mathrm{ha}^{-1}$ (FAI, 2012).

Application of S and P improves soil fertility status but $\mathrm{S}$ alone cannot influence $\mathrm{P}$ 
availability. Individual application of different levels of $\mathrm{P}$ and $\mathrm{S}$ showed significant effect on yield attributes. Among them plant height, number of primary branch per plant, number of leaves per plant, stalk yield increased significantly up to $50 \mathrm{~kg} \mathrm{Pha}^{-1}$. On the other hand, number of pods per plant, number of seeds per plant, thousand seed weight, grain yield and biological yield increases up to 30 $\mathrm{kg} \mathrm{Pha}^{-1}$.

However in case of $\mathrm{S}$, the positive response was observed only up to $25 \mathrm{~kg} \mathrm{~S} \mathrm{ha}^{-1}$. The combined application of P @ $30 \mathrm{~kg} \mathrm{ha}^{-1}$ and S @ $25 \mathrm{~kg} \mathrm{ha}^{-1}$ give rise to the highest number of pods per plant, thousand seed weight $(\mathrm{g})$ and in turn produce highest grain yield (Fahmina et al., 2013). P can affect the adsorption and consequently retention and/or the availability of sulphur in soils. Field studies have shown reduced pasture growth on high $\mathrm{P}$ application and high stocking rates.

The possible replacement of sulphate by other anions of greater penetrating or coordinating ability was occurred (Ensminger, 1954). Sulphate adsorption is completely stopped by the presence of two-thirds of the equivalent amount of phosphate compared to sulphate. It has been demonstrate that rate of downward movement of adsorbed sulphate and the extent of leaching depend on the quantity of $\mathrm{P}$ applied.

\section{Materials and Methods}

A pot experiment was conducted on a sandy clay loam soil having $\mathrm{pH} 7.3$, low in organic carbon $(0.38 \%)$, low in available $\mathrm{N}(146 \mathrm{~kg}$ $\left.\mathrm{ha}^{-1}\right)$, rich in available $\mathrm{P}\left(35.8 \mathrm{~kg} \mathrm{ha}^{-1}\right)$, medium in available $\mathrm{K}\left(185.5 \mathrm{~kg} \mathrm{ha}^{-1}\right)$ and deficient in available $S\left(14.5 \mathrm{~kg} \mathrm{ha}^{-1}\right)$ with electrical conductivity $0.23 \mathrm{dS} / \mathrm{m}$ and CEC $12.01 \mathrm{Cmol}(\mathrm{p}+) \mathrm{kg}^{-1}$. The experiment was laid out in a FCRD combination with three levels of $\mathrm{P}(0,10$ and $20 \mathrm{mg} / \mathrm{kg}$ of soil $)$ and four levels of $S(0,10,20$ and $30 \mathrm{mg} / \mathrm{kg}$ of soil) applied through potassium dihydrogen phosphate and elemental sulphur. A basal dose of $\mathrm{N}$ and $\mathrm{K}$ through urea and murate of potash was applied uniformly with all the treatments. Sesamum seed (cv. Tarun) was sown @ 4 seeds per pot. Since the experiment was conducted under net house during kharif season. Prophylactic plant protection measures were taken to protect the crop from insects and diseases. Before sowing, the seed was treated with bavistin @ $2 \mathrm{~g} / \mathrm{kg}$ to protect from seed borne diseases. Spraying of imidacloprid (17.8 SL) @ 1ml/ 4 litres was done to protect the crop from damage of sucking insects.

Required quantities of fertilizers for $10 \mathrm{~kg}$ soil were calculated and applied in solution form using urea, $\mathrm{KH}_{2} \mathrm{PO}_{4}$ and $\mathrm{KCl}$ as source of $\mathrm{N}$, $\mathrm{P}$ and $\mathrm{K}$ respectively. Sulphur was applied in the form of elemental sulphur $(80 \%$ S) 24 days before sowing for complete oxidation. $75 \%$ of the dose of $\mathrm{N}$ and full dose of $\mathrm{K}_{2} \mathrm{O}$ were applied as basal. Left over dose of nitrogen was added at flowering stage. However there are 3 levels of Phosphorus and 4 levels of Sulphur, which was applied in the doses of $0,10,20$ and $0,10,20,30 \mathrm{mg}$ per $\mathrm{kg}$ of soil which constituted the twelve treatment combinations. Nitrogen and potassium were applied as recommended doses in all the pots.

\section{Height of plants}

The height of plants was measured from the surface of soil to the tip of plant at 30,60 and 90 days after sowing with the help of a meter scale.

\section{Chlorophyll content}

Chlorophyll content in the leaves of plants was measured by using of spadometer in SPAD units at 35 and 70 days after transplanting. 


\section{Dry matter accumulation}

Dry matter production was recorded at the time of harvest; the samples were dried in an electric oven at $60 \pm 2^{0} \mathrm{C}$ till a constant weight was achieved. The weight was recorded and expressed as average dry matter per pot.

\section{Plant stand (per pot)}

Plant stand per pot was two after thinning.

\section{Yield Attributes}

\section{Number of capsules pot ${ }^{-1}$}

Numbers of capsules pot ${ }^{-1}$ were counted at the time of harvesting.

\section{Number of seeds capsule ${ }^{-1}$}

At the time of threshing, 10 capsules were randomly selected from each pot and their total seeds were counted to record the average number of seeds capsule ${ }^{-1}$.

\section{Test weight}

One thousand seeds were counted from the sample drawn randomly from the finally winnowed and cleaned produce of each pot and their weight was recorded as test weight.

\section{Number of branches plant ${ }^{-1}$}

Numbers of primary and secondary branches were counted after 90 DAS.

\section{Seed yield pot ${ }^{-1}$}

After harvesting of crop, seeds were separated from the plant, kept in paper bags and dried in hot air oven at $60 \pm 2{ }^{\circ} \mathrm{C}$ till the weight became constant and seed yield $\left(\operatorname{pot}^{-1}\right)$ was computed

\section{Stalk yield}

After harvesting of crop, seeds were separated and plant samples were kept in paper bags, dried in hot air oven at $60 \pm 2^{\circ} \mathrm{C}$ till the weight became constant and straw yield pot $^{-}$ ${ }^{1}$ ) was recorded.

\section{Dry matter production}

After harvesting, plant samples were kept in paper bags and dried in hot air oven at $60^{\circ} \mathrm{C} \pm$ $2^{\circ} \mathrm{C}$ till the weight became constant. The total dry matter production was obtained by summation of grain yield $\left(\mathrm{pot}^{-1}\right)$ and straw yield $\left(\right.$ pot $\left.^{-1}\right)$ was done.

\section{Harvest index}

Harvest index (HI) was computed by using the formula outlined by Singh and Stoskopf (1971).

Harvest index (HI) was calculated as follows:

$\mathrm{HI}(\%)=($ Economic yield $/$ Total biological yield) $\times 100$

\section{Results and Discussion}

\section{Growth attributes}

\section{Plant height}

Data presented in Table 1 revealed that a significant increase in plant height (140.93 $\mathrm{cm})$ at 90 DAS was recorded with the application of sulphur $20 \mathrm{mg} \mathrm{kg}^{-1}$ of soil as compared the plant height obtained from the $\mathrm{S}$ levels of $10 \mathrm{mg} \mathrm{kg}^{-1}(138.06 \mathrm{~cm})$ followed by $30 \mathrm{mg} \mathrm{kg}^{-1}(137.60 \mathrm{~cm})$ and control $(123.25$ $\mathrm{cm})$. Almost similar trend was noticed for the plant height recorded at 30 and 60 DAS. Plant height increased with increase levels of $S$ application. This might be possible because $S$ enhances the cell division, cell multiplication 
and tissue differentiation, which ultimately increase the plant height and branching in plant. The increase in plant height as observed in the experiment may be due to the favorable effects of sulphur on $\mathrm{N}$-metabolism and consequently on the vegetative growth of soybean plant. Similar findings were also reported in groundnut (Aktar et al., 2001).

\section{Chlorophyll content}

Data pertaining to chlorophyll content (leaf SPAD value) were presented in Table 1. There was significant increase in chlorophyll content (37.78) at 30 DAS was recorded with the application of P @ $20 \mathrm{mg} \mathrm{kg}^{-1}$ of soil. The data revealed that the significant increase in chlorophyll content (30 DAS) was recorded with the application of sulphur $20 \mathrm{mg} \mathrm{kg}^{-1}$ of soil (leaf SPAD value, 38.86) than the chlorophyll content obtained from the treatment of $10 \mathrm{mg} \mathrm{kg}^{-1}$ (37.73) followed by $30 \mathrm{mg} \mathrm{kg}$ (36.39) and control (35.51). Almost similar trend was noticed for the chlorophyll content recorded at 60 DAS. The increase in chlorophyll content may be attributed due to adequate supply of nitrogen.

\section{Number of branches plant ${ }^{-1}$}

Application of phosphorus significantly influenced the number of primary branches plant $^{-1}$ (Table 1). The highest number of primary branches plant ${ }^{-1}$ (3.38) was recorded with P @20 mg kg-1 of soil which was statistically same with control pot (3.00) but no. of secondary branches plant ${ }^{-1}$ was increased with application of P @ $10 \mathrm{mg} \mathrm{kg}^{-1}$ of soil at 90 DAS. The lowest number of primary branches plant $^{-1}$ (2.67) was recorded in the control treatment. The increase number of primary branches plant $^{-1}$ may be due to favorable effects of phosphorus on hormonal balance that helped proper growth and development of the sesamum plant. Sulphur fertilizer application also caused significant variations in number of primary branches of sesamum. Among the different doses, $20 \mathrm{mg}$ $\mathrm{S} \mathrm{kg}^{-1}$ application showed the highest number of primary branches plant $^{-1}$ (3.94) and secondary branches plant ${ }^{-1}(8.00)$ at 90 DAS. On the contrary, the lowest number of primary branches plant ${ }^{-1}$ (2.89) was recorded in $\mathrm{S}_{0}$ fertilizer application. Aktar et al., (2013) reported similar observations with $30 \mathrm{~kg} \mathrm{~S}$ ha 1 application.

\section{Yield Attributes}

\section{No. of capsule per pot}

Significant increase in number of capsule $\operatorname{pot}^{-1}$ was observed at various levels of phosphorus application (Table 2). The highest number of capsule $\operatorname{pot}^{-1}$ (36.75) was recorded with application of P @ $20 \mathrm{mg} \mathrm{kg}^{-1}$ in soil. The lowest number of capsule pot $^{-1}$ (32.33) was recorded in control pot. These findings are in agreement with Aktar et al., (2013).Different doses of sulphur fertilizer application increased number of capsules pot $^{-1}$. Among the different doses of fertilizers, $\mathrm{S} @ 20 \mathrm{mg} \mathrm{kg}^{-1}$ of soil resulted in production of highest number of capsule pot $^{-1}$ (37.44) which was followed by $30 \mathrm{mg} \mathrm{S} \mathrm{kg}^{-1}$ of soil (35.67) Whereas, the lowest number of capsules plant ${ }^{-1}$ (19.21) was recorded in pots which did not receive any $S$ application. Supply of sulphur in adequate amount also helps in the development of floral primordial i.e. reproductive parts, which results in the development of capsules and seeds in plant. Similar results have also been reported by Verma et al., (2014) and Raja et al., (2007) in sesame.

\section{No. of seeds per capsule}

Data presented in Table 2 revealed that a significant increase in no. of seed per capsule was recorded with the application of P@20 $\mathrm{mg} \mathrm{kg}-1$ of soil $(60.08)$ than the no. of seed 
per capsule obtained from the treatment of 10 $\mathrm{mg} \mathrm{kg}^{-1}$ (59.50) followed by control (49.83). The highest number of seeds capsule ${ }^{-1}$ was recorded with $20 \mathrm{mg} \mathrm{P} \mathrm{kg}^{-1}$ of soil which was statistically similar with that obtained from the application of $10 \mathrm{mg} \mathrm{P} \mathrm{kg}^{-1}$ of soil.

The lowest number of seeds capsule ${ }^{-1}$ was recorded in no phosphorus application treatment. The result confirms with the findings of Aktar et al., (1990). Sulphur fertilizer application increased number of seeds capsule ${ }^{-1}$. There was significant difference among the different doses of $S$ fertilizer application. The lowest number of seeds capsule ${ }^{-1}$ (45.89) was recorded in the control treatment. The highest number of seeds plant ${ }^{-1}$ (63.33) was recorded with $20 \mathrm{mg}$ $\mathrm{S} \mathrm{kg}^{-1}$ of soil which was statistically similar with that obtained from the application of 20 $\mathrm{mg} \mathrm{S} \mathrm{kg}$ of soil. The present findings are in accordance with the observations of Dubey et al., (1997) who reported increase in seeds plant $^{-1}$ of linseed with the application of sulphur.

\section{Test weight}

It is obvious from the data (Table 2) that phosphorus application increased test weight in sesamum and the highest test weight (2.75 g) was recorded with the application of $\mathrm{P}$ @20 mg kg-1 of soil which was statistical similar with that obtained from application of P@ $10 \mathrm{mg} \mathrm{kg}^{-1}$ of soil (2.74 g). This may be due to large amount of phosphorus found in the seed and capsules, which is considered essential for seed formation and size of seeds. The result confirms with the findings of Aktar et al., (2013). S application increased the test weight significantly and the maximum test weight $(2.82 \mathrm{~g})$ was recorded with $20 \mathrm{mg} \mathrm{S}$ application $\mathrm{kg}^{-1}$ of soil. These results are in agreement with the findings of Puste (2015).

Table.1 Effect of different levels of $\mathrm{P}$ and $\mathrm{S}$ on growth attributes of sesame

\begin{tabular}{|c|c|c|c|c|c|c|c|}
\hline \multirow{2}{*}{ Treatment } & \multicolumn{3}{|c|}{ Plant height (cm) } & \multicolumn{2}{c|}{$\begin{array}{c}\text { Chlorophyll content } \\
\text { (SPAD value) }\end{array}$} & $\begin{array}{c}\text { Number of 1 } \\
\text { branches }\end{array}$ & $\begin{array}{c}\text { Number of } \\
\text { secondary branches }\end{array}$ \\
\cline { 2 - 8 } & $\begin{array}{c}30 \\
\text { DAT }\end{array}$ & $\begin{array}{c}\mathbf{6 0} \\
\text { DAT }\end{array}$ & $\begin{array}{c}\mathbf{9 0} \\
\text { DAT }\end{array}$ & $\mathbf{3 0}$ DAT & $\mathbf{6 0}$ DAT & & \\
\hline $\mathbf{P}_{\mathbf{0}}$ & 30.61 & 125.24 & 130.72 & 36.30 & 31.24 & 3.25 & 5.29 \\
\hline $\mathbf{P}_{\mathbf{1 0}}$ & 32.41 & 132.96 & 139.18 & 37.28 & 32.84 & 3.38 & 5.67 \\
\hline $\mathbf{P}_{\mathbf{2 0}}$ & 32.29 & 133.71 & 139.33 & 37.78 & 32.43 & 3.00 & 4.54 \\
\hline $\mathbf{S E m} \pm$ & 0.38 & 0.39 & 0.45 & 0.53 & 0.58 & 0.14 & 0.16 \\
\hline $\mathbf{C D}(\mathbf{0 . 0 5})$ & $1.13^{*}$ & $1.14^{*}$ & $1.32^{*}$ & 1.57 & 1.72 & 0.41 & $0.48^{*}$ \\
\hline $\mathbf{C V}$ & 4.20 & 1.03 & 1.14 & 5.01 & 6.34 & 15.34 & 11.17 \\
\hline $\mathbf{S}_{\mathbf{0}}$ & 28.74 & 123.25 & 129.03 & 35.51 & 31.08 & 2.89 & 4.00 \\
\hline $\mathbf{S}_{\mathbf{1 0}}$ & 32.71 & 131.98 & 138.06 & 37.73 & 32.48 & 3.17 & 5.06 \\
\hline $\mathbf{S}_{\mathbf{2 0}}$ & 33.78 & 135.46 & 140.93 & 38.86 & 33.92 & 3.94 & 8.00 \\
\hline $\mathbf{S}_{\mathbf{3 0}}$ & 31.84 & 131.83 & 137.6 & 36.39 & 31.18 & 2.83 & 3.61 \\
\hline $\mathbf{S E m}_{ \pm}$ & 0.44 & 0.45 & 0.52 & 0.62 & 0.68 & 0.16 & 0.19 \\
\hline $\mathbf{C D}(\mathbf{0 . 0 5})$ & $1.30^{*}$ & $1.32^{*}$ & $1.52^{*}$ & $1.82^{*}$ & $1.99 *$ & $0.48^{*}$ & $0.56^{*}$ \\
\hline $\mathbf{C V}$ & 4.20 & 1.03 & 1.145 & 5.01 & 6.34 & 15.34 & 11.17 \\
\hline $\mathbf{P} \times \mathbf{S}$ & $\mathrm{S}$ & $\mathrm{S}$ & $\mathrm{S}$ & $\mathrm{NS}$ & $\mathrm{NS}$ & $\mathrm{S}$ & $\mathrm{S}$ \\
\hline
\end{tabular}


Int.J.Curr.Microbiol.App.Sci (2017) 6(11): 3278-3285

Table.2 Effect of different levels of $\mathrm{P}$ and $\mathrm{S}$ on yield attributes of sesame

\begin{tabular}{|c|c|c|c|c|c|c|c|}
\hline Treatment & $\begin{array}{c}\text { No. of capsule } \\
\text { per pot }\end{array}$ & $\begin{array}{c}\text { No. of seed per } \\
\text { capsule }\end{array}$ & $\begin{array}{c}\text { Test } \\
\text { weight (g) }\end{array}$ & $\begin{array}{c}\text { Grain yield (g } \\
\left.\text { pot }^{-1}\right)\end{array}$ & $\begin{array}{c}\text { Stalk yield (g } \\
\left.\text { pot }^{-1}\right)\end{array}$ & $\begin{array}{l}\text { Total dry matter } \\
\text { yield }\left(\mathrm{g} \mathrm{pot}^{-1}\right)\end{array}$ & $\begin{array}{c}\text { Harvest index } \\
(\%)\end{array}$ \\
\hline $\mathbf{P}_{\mathbf{0}}$ & 32.33 & 49.83 & 2.68 & 8.46 & 35.64 & 44.10 & 18.85 \\
\hline $\mathbf{P}_{10}$ & 35.75 & 59.50 & 2.74 & 8.97 & 36.63 & 45.60 & 20.39 \\
\hline $\mathbf{P}_{20}$ & 36.75 & 60.08 & 2.75 & 8.57 & 35.19 & 43.76 & 19.41 \\
\hline $\mathrm{SEm} \pm$ & 0.65 & 1.03 & 0.017 & 0.30 & 1.11 & 1.12 & 0.72 \\
\hline CD (0.05) & $1.92 *$ & $3.03 *$ & $0.050 *$ & 0.88 & 3.27 & 3.30 & 2.12 \\
\hline $\mathbf{C V}$ & 6.49 & 6.35 & 2.19 & 12.00 & 10.69 & 8.71 & 12.85 \\
\hline $\mathbf{S}_{\mathbf{0}}$ & 31.11 & 45.89 & 2.56 & 6.87 & 31.40 & 38.27 & 18.83 \\
\hline $\mathbf{S}_{10}$ & 35.56 & 57.33 & 2.73 & 9.01 & 36.99 & 46.00 & 19.61 \\
\hline $\mathbf{S}_{20}$ & 37.44 & 63.33 & 2.82 & 10.62 & 40.84 & 51.46 & 20.94 \\
\hline $\mathbf{S}_{30}$ & 35.67 & 59.33 & 2.77 & 8.18 & 35.38 & 43.51 & 18.82 \\
\hline $\mathrm{SEm} \pm$ & 0.75 & 1.19 & 0.019 & 0.34 & 1.28 & 1.30 & 0.83 \\
\hline CD (0.05) & $2.21 *$ & $3.50 *$ & $0.058 *$ & $1.01 *$ & $3.77 *$ & $3.81 *$ & 2.45 \\
\hline $\mathbf{C V}$ & 6.49 & 6.35 & 2.19 & 12.00 & 10.69 & 8.71 & 12.85 \\
\hline $\mathbf{P} \times \mathbf{S}$ & $\mathrm{S}$ & $\mathrm{S}$ & $\mathrm{S}$ & $\mathrm{S}$ & NS & NS & NS \\
\hline
\end{tabular}




\section{Seed yield}

Data presented in Table 2 revealed that the highest grain yield of sesamum $\left(8.97 \mathrm{~g} \mathrm{pot}^{-1}\right)$ was obtained in the treatment of $10 \mathrm{mg} \mathrm{P} \mathrm{kg}^{-1}$ of soil which was statistically at par with that obtained from $20 \mathrm{mg} \mathrm{P} \mathrm{kg}^{-1}$ of soil $(8.57 \mathrm{~g}$ pot $\left.^{-1}\right)$. The lowest grain yield $\left(8.46 \mathrm{~g} \mathrm{pot}^{-1}\right)$ was recorded in the $\mathrm{P}_{0} \mathrm{~S}_{0}$ treatment. These results are in agreement with the findings of Aktar et al., (2000) who reported the increase in grain yield of soybean with the application of $\mathrm{P}$ and the highest grain yield was recorded with $60 \mathrm{~kg} \mathrm{P} \mathrm{ha}^{-1}$.

Sulphur fertilizer application also increased grain yield of sesamum (Table 2) and the highest grain yield $(10.62 \mathrm{~g} / \mathrm{pot})$ was recorded in $\mathrm{S}_{20}\left(20 \mathrm{mg} \mathrm{S} \mathrm{kg}^{-1}\right.$ of soil). It is possible that higher levels of $\mathrm{S}$ application, vigorous plant growth might have produced more photosynthates. Efficient partitioning of accumulated photosynthates, which resulted from $S$ application that enhances yield attributes Aktar et al., (2004) found highest grain yield with the application of $30 \mathrm{~kg} \mathrm{~S} \mathrm{ha}^{-1}$.

\section{Stalk yield}

Data presented in Table 2 revealed that the highest stalk yield of sesamum (36.53 $\left.\mathrm{g} \mathrm{pot}^{-1}\right)$ was recorded with $10 \mathrm{mg} \mathrm{P} \mathrm{kg}{ }^{-1}$ of soil. whereas; lowest stalk yield (35.19 $\mathrm{g} \mathrm{pot}^{-1}$ ) was recorded in the treatment of $20 \mathrm{mg} \mathrm{P} \mathrm{kg}^{-1}$ of soil. The findings are in agreement with the results obtained by Sacchidanand et al., (1980) who observed that straw yields of soybean increased with the application of P @ $20 \mathrm{~kg} \mathrm{P}_{2} \mathrm{O}_{5} \mathrm{ha}^{-1}$ which was statistical similar with that obtained from application of $40 \mathrm{~kg} \mathrm{P}$ $\mathrm{ha}^{-1}$.Application of sulphur significantly increased stalk yield of sesamum and the highest stalk yield of sesamum (40.84 $\left.\mathrm{g} \mathrm{pot}^{-1}\right)$ was obtained with $20 \mathrm{mg} \mathrm{S} \mathrm{kg}{ }^{-1}$ of soil. Whereas, lowest stalk yield $\left(29.43 \mathrm{~g} \mathrm{pot}^{-1}\right)$ was recorded at the control treatment (P0S0). On the other hand, the lowest stalk yield of sesamum was recorded in the control treatment $(29.43 \mathrm{~g} / \mathrm{pot})$. These findings agree with the observation made by Tomar et al., (2004) and Majumdar et al., (2001) who reported that straw yield of soybean increased significantly with the combined application of phosphorus and sulphur in increasing rate.

\section{Dry matter production}

Data presented in Table 2 revealed that total dry matter yield of sesamum (45.60 $\left.\mathrm{g} \mathrm{pot}^{-1}\right)$ was recorded with $\mathrm{P}_{10} \mathrm{~S}_{0}$ treatment $(10 \mathrm{mg} \mathrm{P}$ $\mathrm{kg}^{-1}$ of soil). The lowest biological yield (43.76 $\mathrm{g} \mathrm{pot}^{-1}$ ) was recorded in the control treatment. Different doses of sulphur fertilizer application increased total dry matter yield of sesamum (Table 2) and the highest dry matter yield of sesamum (51.46 $\left.\mathrm{g} \mathrm{pot}^{-1}\right)$ was obtained from the application of $20 \mathrm{mg} \mathrm{S} \mathrm{kg}^{-1}$ of soil the lowest biological yield of soybean (38.27 $\mathrm{g} / \mathrm{pot})$ was recorded in the control treatment. $S$ application enhanced higher dry matter accumulation in plant at all the stages. According to Khare et al., (1999), S application greatly influences chlorophyll synthesis, carbohydrate as well as protein metabolism and finally results in improvement of growth characters contributing to higher dry matter accumulation in plants.

\section{Harvest index.}

Data represented in Table 2 showed that the application of P @ $10 \mathrm{mg} \mathrm{kg}^{-1}$ of soil recorded maximum harvest index (20.39\%). It was higher by 14.4 and $5.7 \%$ respectively over control and $10 \mathrm{mg} \mathrm{S} \mathrm{kg}{ }^{-1}$ of soil. However, this level was at par with $20 \mathrm{mg} \mathrm{S} \mathrm{kg}^{-1}$ of soil. Harvest index did not differ significantly due to phosphorus fertilization. Application of 20 $\mathrm{mg} \mathrm{S} \mathrm{kg}{ }^{-1}$ of soil recorded maximum harvest index $(20.94 \%)$ followed by $10 \mathrm{mg} \mathrm{S} \mathrm{kg}{ }^{-1}$ of soil $(19.61 \%)$ and control $(18.83 \%)$ Increase 
in yield attributes and harvest index of sesame due to sulphur fertilization has also been reported by Saren et al., (2004) and Tripathi et al., (2007) in sesame.

A significant increase in seed and stalk yield of sesamum could be achieved by application of sulphur in an alluvial soil having high available phosphorus. Among the various treatments tested, maximum seed yield was obtained with combined application of $20 \mathrm{mg}$ $\mathrm{kg}^{-1}$ phosphorus and sulphur which was $77.58 \%$ higher over control.

\section{References}

Akter, F., Nurul Islam, Md., Shamsuddoha, A.T.M., Bhuiyan, M. S. I. and Shilpi, S. (2013). Effect of Phosphorus and Sulphur on Growth and Yield of Soybean. International Journal of Bioresource and Stress Management, 4(4): 555-560.

Majumdar, B., Venkatesh, M.S., Lal, B. and Kumar, K. (2001). Response of soybean to phosphorus and sulphur in acid alfisol of Meghalaya. Indian Journal of Agronomy, 46(3): 500-505.

Sangale, R.V. and Sonar, K.R. (2004). Yield and quality of soybean as influenced by sulphur application. Journal of Maharashtra Agricultural Universities, 9(1):117-118.

Saren, B.K. Nandi, P. and Tudu, S. (2004). Effect of irrigation and sulphur on yield attributes, yield, oil content and oil yield and consumptive use efficiency of summer sesame (Sesamum indicum L.). Journal of Oilseeds Research, 22(2): 383-384.

Tomar, S.J.; Tomar, T.V.S. and Singh, S. (1992). Effect of fertility levels of growth, yield, quality of mustard $(B$. juncea L.). Indian Journal of Agronomy, 37: 76-78.

Tripathi, M.L. Rajput, R.L. and Chaursia. S.K. (2007). Effect of sources and levels of sulphur on yield attributes, yield and economics of sesame. Advances in Plant Sciences, 20(2): 501502.

\section{How to cite this article:}

Pagal, A.K., A.P. Singh, S. Behera and Meher, C. 2017. Effect of Different Level of Sulphur and Phosphorus on Growth and Yield Attributes of Sesamum. Int.J.Curr.Microbiol.App.Sci. 6(11): 3278-3285. doi: https://doi.org/10.20546/ijcmas.2017.611.384 